\title{
Synthesis, Physicochemical, Thermal and Fluorescence Studies of Cobalt(II) Complex with Tridentate (ONS) Schiff Base Ligand Derived From 2-Aminophenol and 2-Acetylthiophene
}

\author{
Manara A. Ayoub, Eman H. AbdEInasser, M. A. Abedel-aziz \\ and Mariam G.R.*.
}

*Chemistry Dep., Faculty of Girls for Arts, Science and Education, Ain Shams University, Cairo, Egypt, P.O. BOX 11757, Egypt.

\begin{abstract}
A tridentate Schiff base ligand HL(ATS), N-[2-acetylthiophene]salicylideneimine was derived from the $1: 1$ condensation of 2-acetyl thiophene and 2-aminophenol was prepared and characterized by elemental analysis, FT-IR, Mass, ${ }^{1} \mathrm{H}-\mathrm{NMR}$, UV-VIS, thermogravimetric analysis and fluorescence spectra. Cobalt(II) complex was obtained by the reaction of the Schiff base ligand (HL) with cobalt(II) hexahydrate in $1: 1$ molar ratio. The cobalt (II) complex have been characterized by elemental analysis, FT-IR, ${ }^{1} \mathrm{H}-\mathrm{NMR}$, Ms, UV-VIS, magnetic moment, molar conductance, thermogravimetric analysis (TGA) and fluorescence spectra. Elemental analysis (CHNS) data proved $1: 1$ (M : L) stoichiometry for the reported cobalt (II) complex. IR spectra showed that cobalt (II) complex was coordinated in metal ions via the imine $\mathrm{N}, \mathrm{O}$ and $\mathrm{S}$ atoms. Magnetic and UV-VIS spectra, showed that the geometrical structure of cobalt(II) complex is an octahedral. The molar conductance data revealed that the cobalt(II) complex is non-electrolyte. Thermogravimetric analysis (TGA) revealed the high thermal stabilities.
\end{abstract}

Keywords: 2-acetyl thiophene and 2-aminophenol, cobalt(II) complex,

*Corresponding Author: E-mail: mariamgirgis635@yahoo.com 


\section{Introduction}

Schiff bases represent one of the most widely utilized classes of ligands in metal coordination chemistry and the chemistry of Schiff bases is an area of increasing interest [Atkins, A et al., 1985 and Raman, $\mathbf{N}$ et al., 2009]. Schiff bases are capable of forming coordinate bonds with many metal ions via azomethine or phenolic groups, and so they have been used for synthesis of metal complexes due to their easy formation and strong metal binding ability [Cozzi, P.G, 2004 and Holm, R.H et al., 2011]. Schiff bases have wide applications in analytical chemistry and catalysis [Dhahagani, K et al., 2014; Small, B.L and Brooker, M, 1998]. The interest in Schiff bases compounds as analytical reagents is increasing since they enable simple and inexpensive determinations of different organic and inorganic substances [Estrela dos Santos, E.R et al., 2003]. Moreover, it was reported that the Schiff bases containing ONS donors have an important role in biochemistry [Saxena, A et al., 1981]. Particular attentions has been devoted to the metal Schiff base complexes. Schiff bases have been widely used as ligands because of the high stability of coordination compounds. There is a continuing interest in metal complexes of Schiff bases because of the presence of hard nitrogen or oxygen and soft sulfur donor atoms in the back bone of these ligands. Schiff base ligand have numerous applications such as fluorescence. Many of tridentate Schiff base ligand showed enhanced fluorescence. Moreover, luminescent compounds of Schiff base ligand and its transition metal complexes are attracting much current research interest because of their application including emitting materials for organic light, light materials for photofluorescent sensors for organic or inorganic analytes. In the present work, we described the cobalt (II) Schiff base complex produced from the reaction of cobalt (II) chloride 
hexa hydrate with Schiff base ligand HL(ATS) N-[2acetylthiophene]salicylideneimine.

\section{Material and Methods}

\subsection{Materials and physical measurements}

All chemicals were reagent grade quality purchased from commercial sources and used as received. Elemental analysis (CHNS) was performed on a Perkin Elmer 2400 elemental analyzer. FT-IR measurements $(\mathrm{KBr}$ pellets) were carried out on a Shimadzu 8000 FT-IR spectrometer at the central laboratory, Ain Shams University, Egypt .

${ }^{1} \mathrm{H}-\mathrm{NMR}$ measurements were performed on a Varian-mercury 300 MHz spectrometer at the Microanalytical Center, Cairo University, Giza, Egypt. Samples were dissolved in DMSO with TMS as internal reference. Mass spectroscopy measurements of the solid ligands and complexes were carried out on a JEOL JMS-AX500 spectrometer at the National Research Center, Giza, Egypt, magnetic measurements of the complexes were measured by the Gouy method at room temperature using a magnetic susceptibility balance, Sherwood Scientific, Cambridge Science Park, Cambridge England. Thermogravimetric analysis( TG and DTG) were carried out under $\mathrm{N}_{2}$ atmosphere with a heating rate of $10^{\circ} \mathrm{C} / \mathrm{min}$. Using a Shimadzu DT-50 thermal analyzer at the Microanalytical Center, Cairo University, Giza, Egypt. All conductivity measurements were performed in DMF $\left(1 \times 10^{-3} \mathrm{M}\right)$ at $25^{\circ} \mathrm{C}$, by using WAP, GMP 50 conductivitymeter. Ultraviolet spectra were recorded using a Shimadzu UV 1800 spectrophotometer in the range $(200-800 \mathrm{~nm})$ at the Micro analytical Center, Cairo University, Giza, Egypt. The photo luminescent properties of all complexes were studied using a Jenway 6270 fluorimeter ,Ain Shams University. All melting points were measured using an 
ordinary MEL-TEMP II Laboratory device (U.S.A), melting point apparatus.

\section{2- Synthesis}

2.2.1. Synthesis of the tridentate Schiff base ligand N-[2acetylthiophene]salicylideneimine Schiff base HL (ATS).

The ligand was synthesized by slow addition of 2-acetylthiophene (1.09 $\mathrm{ml}, 10 \mathrm{mmole})$ in $50 \mathrm{ml}$ ethanol to 2-aminophenol (1.09 gm, 10 mmole) in $50 \mathrm{ml}$ ethanol. The reaction mixture was heated to reflux for 4 hrs. The dark brown product obtained after cooling was filtered off and washed with different amounts of 1,2-dichloromethane then diethylether, fine crystals were obtained by recrystallization from hot ethanol. The yield was $(1.645 \mathrm{gm}, 70 \%)$, m.p. $\left(157-159^{\circ} \mathrm{C}\right)$, Anal. Calc. for [C $\left.\mathrm{C}_{12} \mathrm{H}_{11} \mathrm{NOS}\right]$ (M.Wt: 217), C, 66.36; H, 5.07 ; N, 6.45; S, 14.75\%, Found: C; 66.40: H; 4.87: N; 6.60: S; 14.60\%; IR (KBr, v/cm $\left.{ }^{-1}\right) ; 3375$ $v(\mathrm{OH}), 1602 v(\mathrm{C}=\mathrm{N}), 1467 v(\mathrm{C}=\mathrm{C}), 743 v(\mathrm{C}-\mathrm{S})$ and $1141 v(\mathrm{C}-\mathrm{O}) .{ }^{1} \mathrm{H}-\mathrm{NMR}$ (300 MHz, DMSO-d ${ }^{6}, \delta(\mathrm{ppm}): 8.879(1 \mathrm{H}, \mathrm{s},-\mathrm{OH}), 6.358-7.722($ phynolic hydrogen and acetyl thiophene sulfur protons, $3.172(3 \mathrm{H}$, $\left.\mathrm{s}, \mathrm{CH}_{3}\right)$.

\subsubsection{Synthesis of the cobalt Schiff base complex.}

A red solution of $\mathrm{CoCl}_{2} \cdot 6 \mathrm{H}_{2} \mathrm{O}(0.455 \mathrm{gm}, 1 \mathrm{mmole})$ in ethanol (50ml) was added gradually with constant stirring to a solution of ligand HL(ATS) $(0.217 \mathrm{gm}, 1 \mathrm{mmole})$ in ethanol $(50 \mathrm{ml})$. The solution was refluxed for $2 \mathrm{hrs}$. A red precipitate was formed and washed with small amounts of ethanol then diethylether. The yield was (0.571 gm, 85\%), m.p. $\left(315-316^{\circ} \mathrm{C}\right.$ ), Anal. Calc. for $\left[\mathrm{C}_{12} \mathrm{H}_{23} \mathrm{NO}_{7} \mathrm{SCl}_{2} \mathrm{Co}\right]$ (2): (M.Wt: 453.9), C, 31.73 ; H, 5.07 ;N, 3.08; S, 7.05\%. Found: C, 31.64; H, 5.23; 
$\mathrm{N}, 3.06 ; \mathrm{S}, 7.03 \%$; IR $\quad\left(\mathrm{KBr}, v / \mathrm{cm}^{-1}\right): 3383 v(\mathrm{OH}), 1591 v(\mathrm{C}=\mathrm{N}), 755 v$ (C-S), $1175 v(\mathrm{C}-\mathrm{O}), 584 v(\mathrm{Co}-\mathrm{N}), 490 v(\mathrm{Co}-\mathrm{O}), 427 v(\mathrm{Co}-\mathrm{S})$ and 412 $v(\mathrm{Co}-\mathrm{Cl})$.

\section{Results and Discussion.}

\subsection{Synthesis and characterization of compounds}

The tridentate Schiff base ligand HL(ATS) was synthesized by the condensation of 2-aminophenol with 2-acetyl thiophene in $\mathrm{EtOH}$ in a (1 : 1) $\mathrm{M}$ ratio under heating on an ultrasonic radiation and the dark brown crystals of the ligand were obtained Scheme (1). The Schiff base ligand was reacted with cobalt (II) complex in $(1: 1) \mathrm{M}$ ratio in ethanol Scheme (2). The ligand obtained was soluble in 1,2-dichloromethane, chloroform, acetonitile $\left(\mathrm{CH}_{3} \mathrm{CN}\right)$, methanol and partially soluble in acetone, dimethylsulfoxide (DMSO). The cobalt (II) complex was insoluble in acetone and methanol but soluble in 1,2-dichloromethane , dimethylformamide (DMF) and dimethylsulfoxide (DMSO).

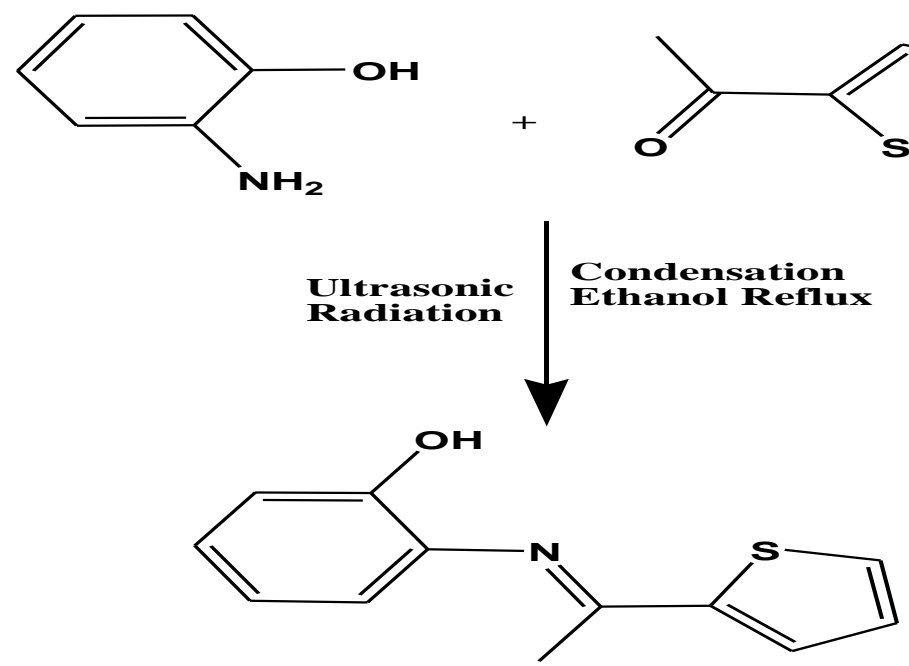

Scheme 1. Schematic representation for the formation of Schiff base ligands N-[2-acetylthiophene]salicylideneimine HL(ATS). 


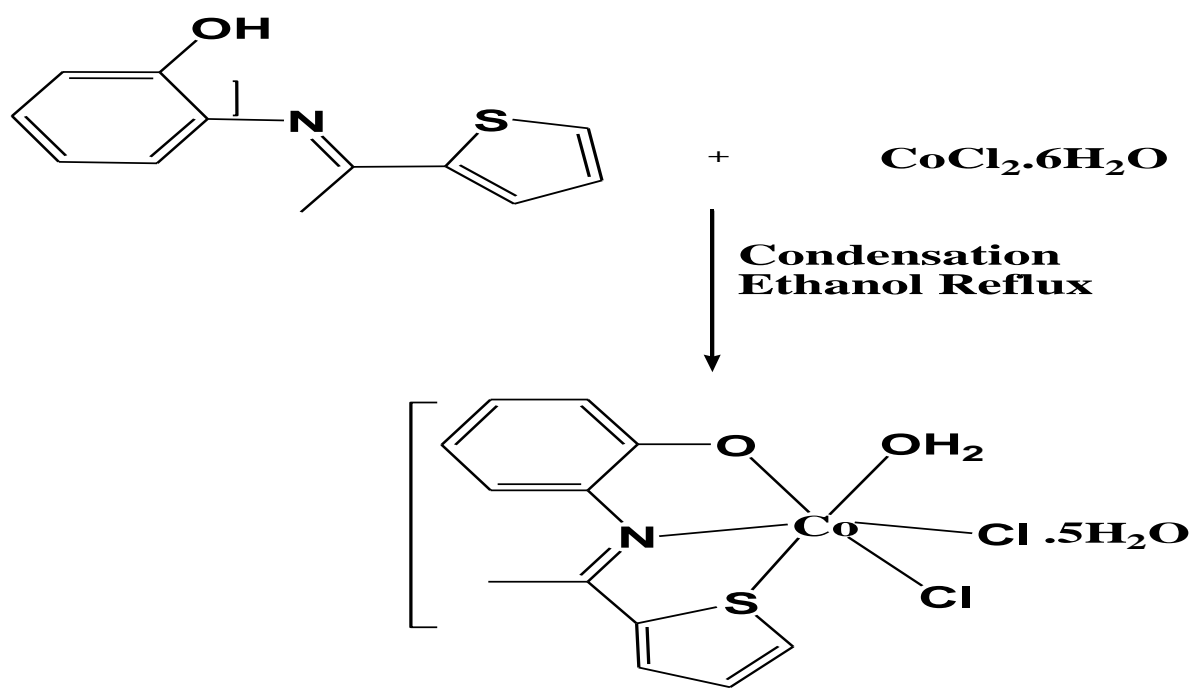

Scheme 2. Schematic representation for the formation of cobalt(II) Schiff base complex.

\subsection{Spectrocopy}

\subsubsection{IR spectra}

In the IR sprctra Figure (1), the IR spectra of the cobalt complexes are compared with the free ligand in order to determine the coordination sites that may be involved in chelation. Upon comparison, it was determined that the $v(\mathrm{OH})$ stretching vibration which is found in the free ligand at $3375 \mathrm{~cm}^{-1}$ disappeared in the spectra of cobalt (II) complex, indicating the participation of $\mathrm{OH}$ group in chelate formation. Cobalt complex showed a broad band in the region $3383 \mathrm{~cm}^{-1}$ assigned to $v(\mathrm{OH})$ of the coordinated or hydrated water molecules associated with the complex which were confirmed by elemental and thermal analysis. But the participation of the $\mathrm{OH}$ group in the complex were evidence from the shift in position of the $\delta(\mathrm{OH})$ in plane deformation vibration from 1267 
$\mathrm{cm}^{-1}$ in the spectrum of the free ligand and found at $1278 \mathrm{~cm}^{-1}$ in the spectra of the complex. Additionally the IR spectrum of the ligand HL (ATS) exhibits medium band at $1141 \mathrm{~cm}^{-1}$ which may be referred to $v(\mathrm{C}-\mathrm{O})$ (phenolic) and shifted toward higher frequency in the cobalt (II) complex. This shift confirms the participation of the phenolic oxygen in coordination to the metal cation. The IR spectra of the free ligand showed a strong band at $1602 \mathrm{~cm}^{-1}$ which is characteristic of the azomethine group. Coordination of the Schiff bases is expected to reduce the electron density and so the azomethine nitrogen $v(\mathrm{C}=\mathrm{N})$ shows a decrease in the stretching frequency for the cobalt (II) complex [Pouralimardan, $\mathbf{O}$ et al., 2007]. The strong to medium bands due to $v(\mathrm{C}-\mathrm{S})$ stretching vibration of acetylthiophene ring appeared at $743 \mathrm{~cm}^{-1}$ in the free Schiff base ligand [Nakamoto, K., 1978]. This band was shifted to $755 \mathrm{~cm}^{-1}$ in $\mathrm{Co}$ (II) complex. These shifts refer to the coordination through acetyl thiophene ring sulfur. Conclusive evidence of the binding is also shown by observation that new bands in the spectra of cobalt (II) complex appear in the region $\left(584,490,427,412 \mathrm{~cm}^{-1}\right)$ characteristic to $v_{\mathrm{M}-\mathrm{N}}, v_{\mathrm{M}-\mathrm{O}}, v_{\mathrm{M}-\mathrm{S}}$ and $\mathrm{v}_{\mathrm{M}-\mathrm{Cl}} \cdot$

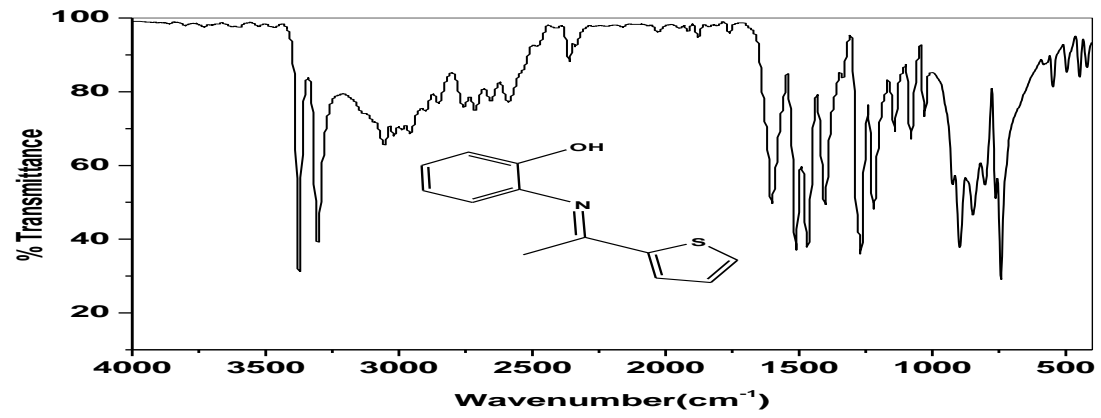

Figure (1): Infrared spectrum of the Schiff base ligand, HL(ATS). 


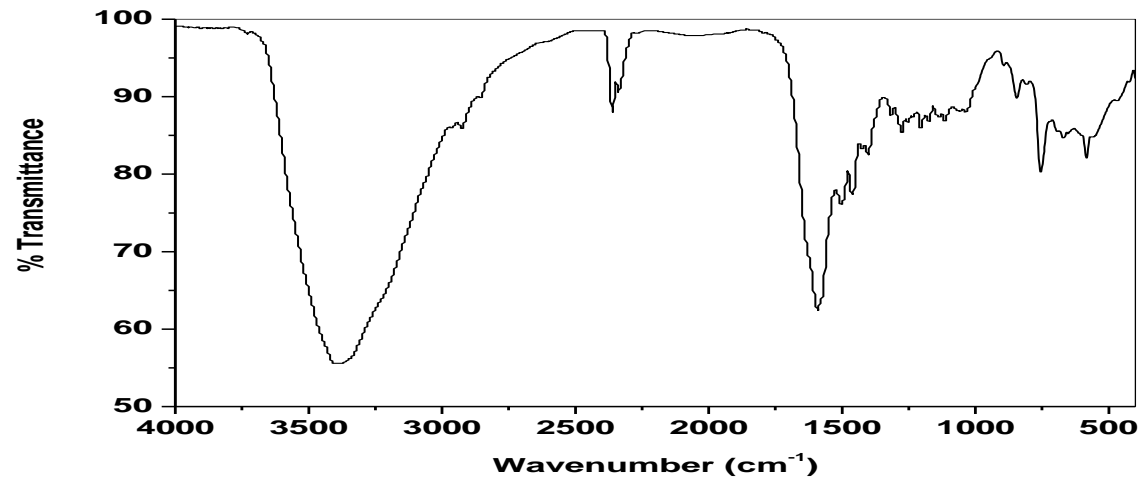

Figure (2): Infrared spectrum of $\left[\mathrm{Co}(\mathrm{HL})(\mathrm{Cl})_{2}\left(\mathrm{H}_{2} \mathrm{O}\right)\right] .5 \mathrm{H}_{2} \mathrm{O}$.

\subsection{2. ${ }^{1} \mathrm{H}-\mathrm{NMR}$}

The structural assignments were further supported by their ${ }^{1} \mathrm{HNMR}$ spectra. ${ }^{1} \mathrm{HNMR}$ spectra of the compounds were obtained in DMSO- $\mathrm{d}^{6}$ at room temperature using TMS as the internal standard. In the ${ }^{1} \mathrm{HNMR}$ spectra, the integral intensities of each signals were found to agree with the number of different types of protons present in the Schiff base ligand. In the Schiff base ligand, Figure (3), the protons peaks of $\mathrm{CH}_{3}$ were appeared in $3.172 \mathrm{ppm}$. The multiplets of the aromatic protons in Schiff base ligand HL(ATS) appeared in the range (6.358 -7.722 ppm) with different multiplicity and coupling constants, the protons peak of $\mathrm{OH}$ were appeared in $8.879 \mathrm{ppm}$. 


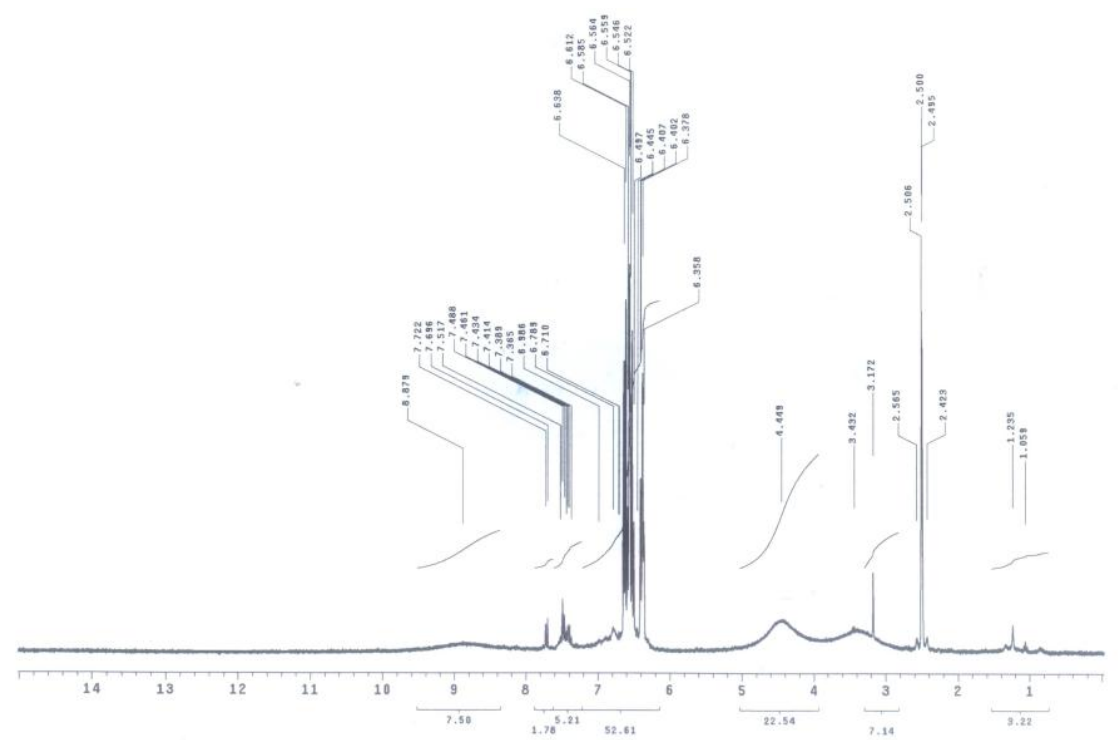

Figure (3): ${ }^{1}$ H-NMR spectrum of the Schiff base ligand, HL(ATS).

\subsubsection{Mass spectra}

Mass spectrometry has been successfully used to confirm the molecular ion peaks of HL(ATS) Schiff base and investigate the fragment species. The fragment pattern of mass spectrum gives an impression for the successive degradation of the target compound with the series of peaks corresponding to various fragments. Also, the peaks intensity gives an idea about the stability of fragments especially with the base peak. The recorded mass spectrum of HL(ATS) Schiff base ligand and Figure (4), confirms the proposed formula of ligand by showing a peak at $217 \mathrm{~m} / \mathrm{z}$ due to molecular ion (parent peak), peak at $218 \mathrm{~m} / \mathrm{z}$ due to $(\mathrm{M}+1)$. The series of peaks 57 (100\%), 69 (65.17\%), 76 (12.36\%), 82 (12.36\%), 94 (60.67\%), 107 (76.40\%), 134 (61.80\%), 175 (64.04\%),175 (64.04\%), 187 (60.67\%) and $202(65.17 \%) \mathrm{m} / \mathrm{z}$ may correspond to various fragments and their intensity gives an idea of the stability. The mass fragmentation pattern of the ligand, HL(ATS) is depicted in Scheme 3. 


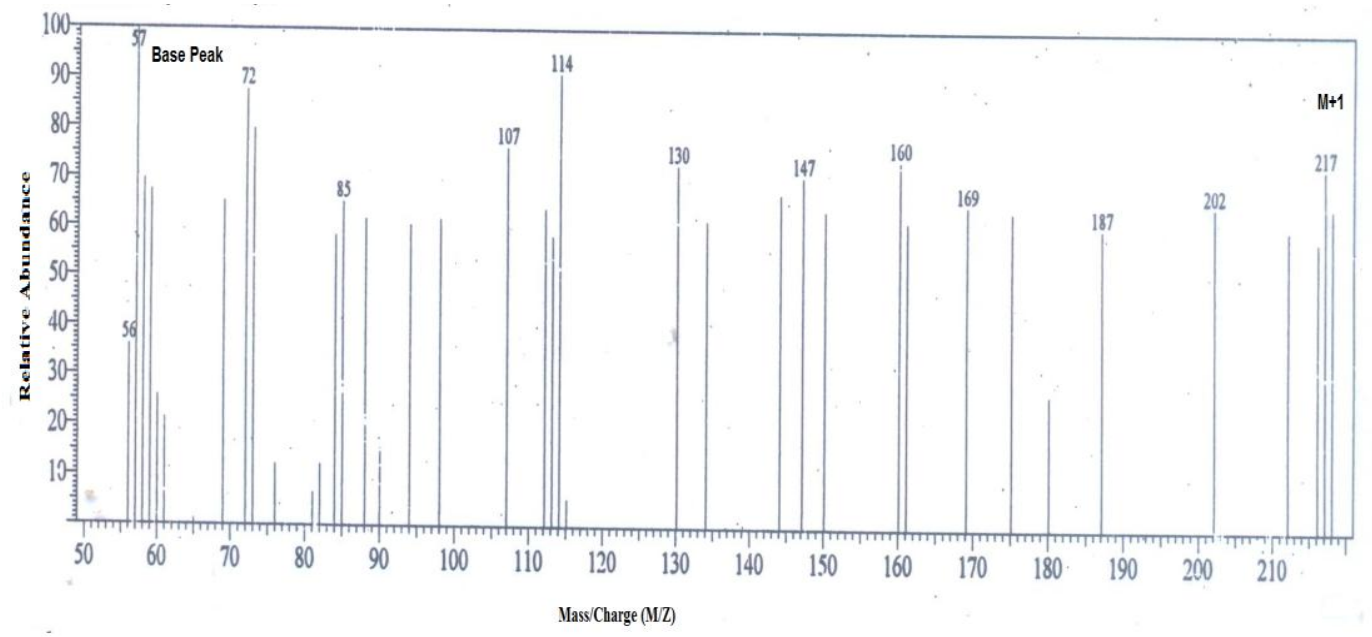

Figure (4): Mass Spectrum of the Schiff Base Ligand, HL(ATS).

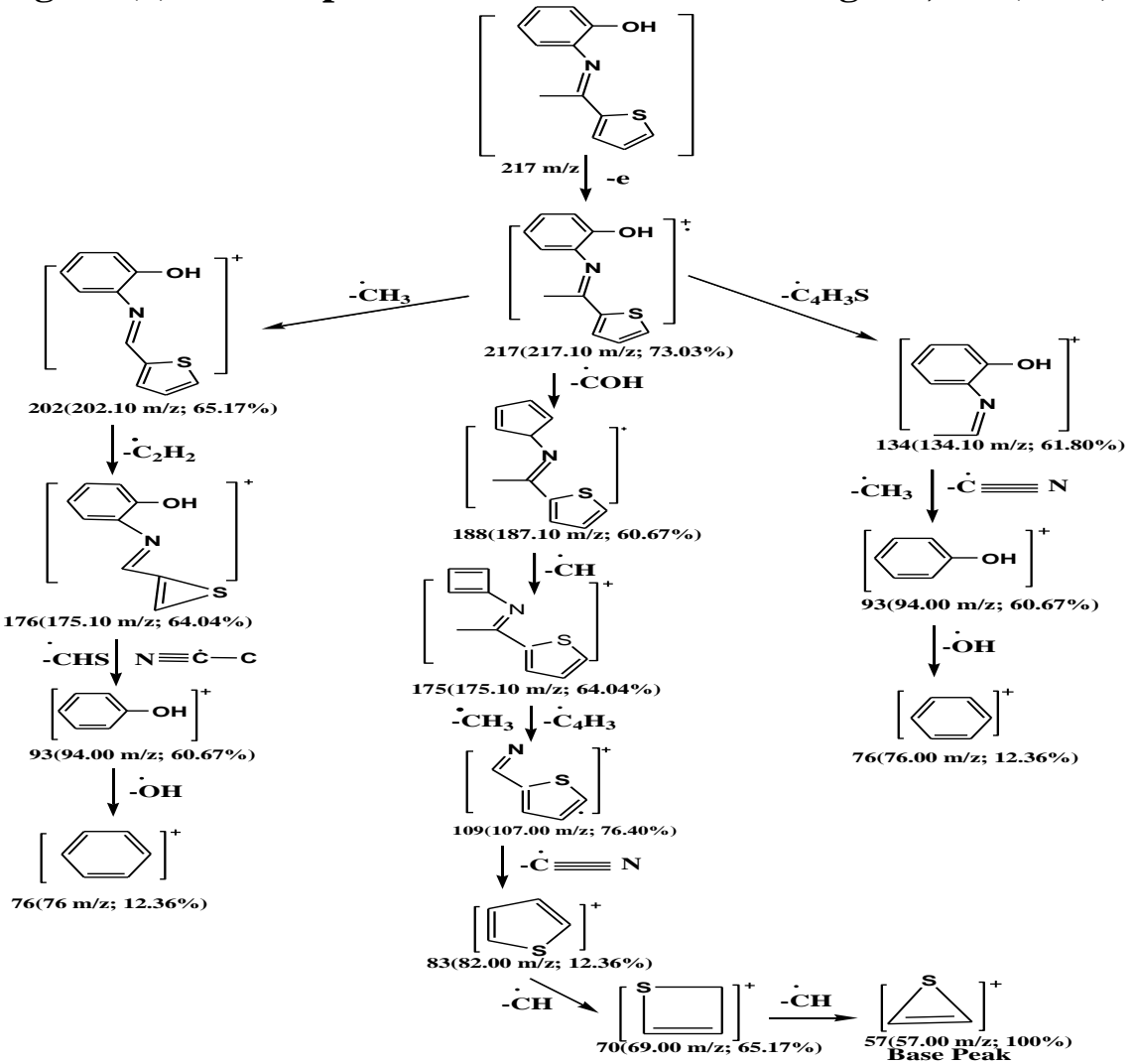

Scheme (3): Mass fragmentation pattern of the Schiff base ligand HL(ATS).

Note: Calc. [Found; Intensity]. 


\subsubsection{Electronic spectra, magnetic and molar conductance.}

The electronic spectra of the Schiff base ligand HL(ATS) and its cobalt(II) complex were investigated in DMF solution. The Schiff base ligand and its cobalt (II) complex exhibit two absorption peaks at a lower energy region (>200 nm). The stronger and higher energy peak, Table (2) was attributed to the $\pi-\pi^{*}$ transition of the azomethine chromophore, the phenyl and thiophene ring, while the weaker and less energetic peak is assigned to the $n \rightarrow \pi^{*}$ transition involving the promotion of the lone pair electron of azomethine nitrogen atom to the antibonding $\pi$ orbital associated with the azomethine group [Bosnich, B., 1968]. The electronic spectrum of the cobalt (II) complex gives three bands, two of them at 736, 597nm [Neelkantana, M.A et al., 2008]. These are assigned to ${ }^{4} \mathrm{~T}_{1 \mathrm{~g}}(\mathrm{~F}) \rightarrow{ }^{4} \mathrm{~T}_{2 \mathrm{~g}}(\mathrm{~F})$ and ${ }^{4} \mathrm{~T}_{1 \mathrm{~g}}(\mathrm{~F}) \rightarrow{ }^{4} \mathrm{~A}_{2 \mathrm{~g}}(\mathrm{~F})$ transition, respectively suggesting that there is an octahedral geometry around $\mathrm{Co}(\mathrm{II})$ ion The third band are at $436 \mathrm{~nm}$ refers to charge transfer band[Lever, A.B.P., 1984].

The magnetic measurements obtained at room temperature for cobalt (II) complex is 5.82 B.M, i.e. close to the spin only value expected for cobalt (II) in octahedral environment. The molar conductance measurements of cobalt (II) complex was dissolved in DMF at $10^{-3} \mathrm{M}$, and the molar conductance of cobalt(II) complex in DMF is $14.75\left(\Omega^{-1} \mathrm{~mol}^{-1} \mathrm{~cm}^{-1}\right)$ is non ionic in nature and non electrolytes [Usha, A.K and Chandra, S., 1992 ]. Table (2): Electronic spectral data (nm), magnetic moment and molar conductance of Schiff base ligand HL(ATS) and its cobalt (II) complex.

\begin{tabular}{|c|c|c|c|c|c|c|}
\hline Compound & $\pi-\pi^{*}$ & $\mathbf{n}-\pi^{*}$ & $\begin{array}{c}\text { Charge } \\
\text { transfer }\end{array}$ & $\mathbf{d - d}$ transition & $\begin{array}{c}\text { Magnetic } \\
\text { moment }\end{array}$ & $\begin{array}{c}\text { Molar } \\
\text { conductance } \\
\boldsymbol{\Omega}^{-1} \mathbf{m o l}^{-1} \mathbf{c m}^{-1}\end{array}$ \\
\hline $\mathbf{H L}(\mathbf{A T S})$ & 266 & 416 & $\cdots \cdots$ & $\cdots \cdots$ & $\cdots \cdots$ & $\cdots \cdots$ \\
\hline$\left[\mathbf{C o}(\mathbf{H L})\left(\mathbf{C l}_{2}\right)\left(\mathbf{H}_{2} \mathbf{O}\right)\right] .5 \mathbf{H}_{2} \mathbf{O}$ & 277 & 412 & 436 & 597,736 & 5.82 & 14.75 \\
\hline
\end{tabular}




\subsubsection{Thermal studies}

The thermal stability of the cobalt (II) complex was investigated using TGA. The thermogravimetric analysis (TGA) was carried out at a heating rate of $10{ }^{\circ} \mathrm{C} / \mathrm{min}$ in a nitrogen atmosphere over a temperature range $\left(25-1000^{\circ} \mathrm{C}\right)$. The thermogravimetric analysis of $\left[\mathrm{Co}(\mathrm{HL})\left(\mathrm{Cl}_{2}\right)\left(\mathrm{H}_{2} \mathrm{O}\right)\right] .5 \mathrm{H}_{2} \mathrm{O}$ involves three decomposition steps, Table (3), Figure (5).The first step from $\left(29-102^{\circ} \mathrm{C}\right)$ showed removal of the four lattice water with an estimated mass loss of 14.923 (Calc., 15.863\%). The second step from $\left(103-309^{\circ} \mathrm{C}\right)$ showed removal of $\mathrm{Cl}_{2}$ with an estimated mass loss of 19.139 (Calc., 18.591\%). In the last step from $\left(311-1000^{\circ} \mathrm{C}\right)$ corresponds to the loss of $2 \mathrm{H}_{2} \mathrm{O}, \mathrm{CN}, \mathrm{OH}, 3 \mathrm{H}_{2}, \mathrm{SH}$ and $\mathrm{CH}_{3}$ with an estimated mass loss of 42.379 (Calc., $42.779 \%$ ). The total mass losses of the decomposition steps is found to be 76.441 (Calc., 77.233).

Table (3): Thermoanalytical results (TGA, DTG) of Co(II) complex.

\begin{tabular}{|c|c|c|c|c|c|c|}
\hline \multirow[b]{2}{*}{ Complex } & \multirow[b]{2}{*}{ Steps } & \multirow[b]{2}{*}{$\begin{array}{l}\text { Temperature range } \\
\left({ }^{\circ} \mathrm{C}\right)\end{array}$} & \multirow[b]{2}{*}{$\begin{array}{l}\text { DTG } \\
\text { Peak }\end{array}$} & \multicolumn{2}{|c|}{ TG Weight Loss \% } & \multirow[b]{2}{*}{ Assignment } \\
\hline & & & & Calc & Found & \\
\hline \multirow[b]{3}{*}[\mathrm{Co}(\mathrm{HL})(\mathrm{Cl})_{2}(\mathrm{H}_{2}\mathrm{O})]{$.5 \mathrm{H}_{2} \mathrm{O}$} & $1^{\text {st }}$ & $29-102$ & 63.5 & 15.863 & 14.923 & $\begin{array}{l}\text { Loss of four } \\
\text { lattice water }\end{array}$ \\
\hline & $2^{\text {nd }}$ & 103-309 & 219 & 18.591 & 19.139 & Loss of $\mathrm{Cl}_{2}$ \\
\hline & $3^{\text {rd }}$ & $311-1000$ & 467 & 42.779 & 42.379 & $\begin{array}{c}\text { Loss of } \\
2 \mathrm{H}_{2} \mathrm{O}, \mathrm{CN} \text {, } \\
\mathrm{OH}, 3 \mathrm{H}_{2}, \\
\mathrm{SH}, \mathrm{CH}_{3}\end{array}$ \\
\hline
\end{tabular}




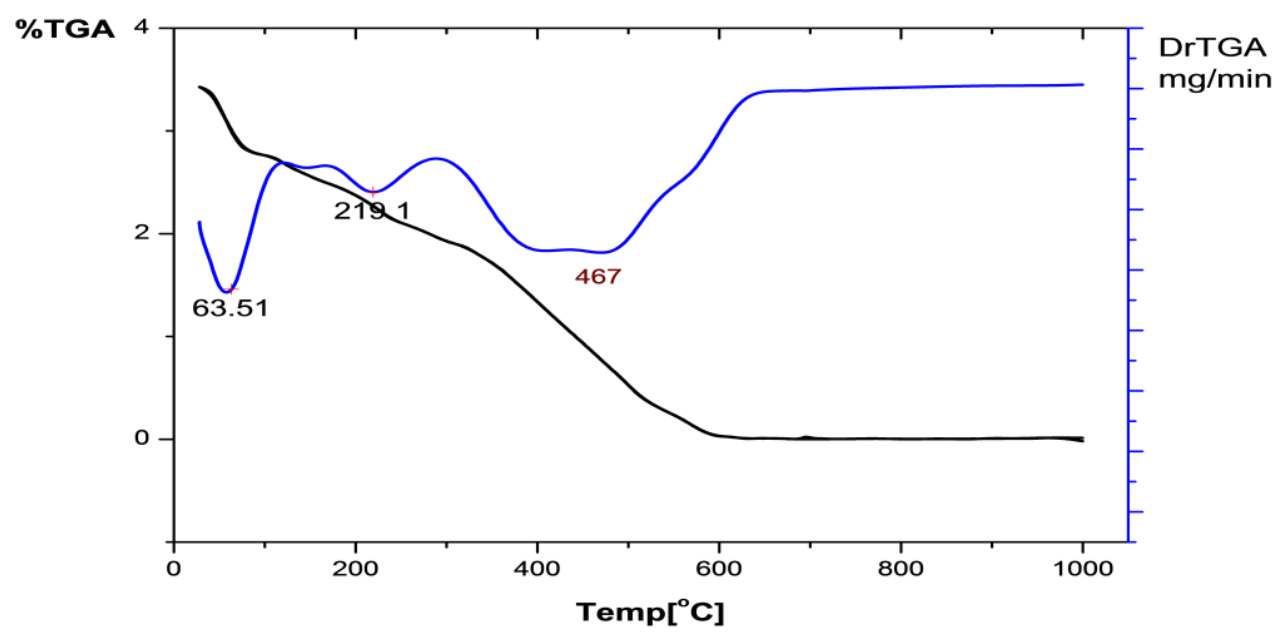

Figure (5): TGA/DTG curves of $\left[\mathrm{Co}(\mathrm{HL})(\mathrm{Cl})_{2}\left(\mathrm{H}_{2} \mathrm{O}\right)\right] .5 \mathrm{H}_{2} \mathrm{O}$.

\subsubsection{Kinetic data}

The kinetic and thermodynamic activation parameters of decomposition processes of complexes namely activation energy $\left(\Delta \mathbf{E}^{*}\right)$, enthalpy of activation $\left(\Delta \mathbf{H}^{*}\right)$, entropy $\left(\Delta \mathbf{S}^{*}\right)$ and Gibbs free energy change of the decomposition ( $\Delta \mathbf{G}^{*}$ ) were evaluated graphically by employing the Coats-Redfern relation [Coats and Redfern, 1964].

$$
\log \left[\log \left\{\mathrm{W}_{\mathrm{f}} /\left(\mathrm{W}_{\mathrm{f}}-\mathrm{W}\right)\right\} / \mathrm{T}^{2}\right]=\log \left[\mathrm{AR} / \mathrm{q} \theta \mathrm{E}^{*}\left(1-2 \mathrm{RT} / \mathrm{E}^{*}\right)\right]-\mathrm{E}^{*} / 2.303 \mathrm{RT}
$$

Where $\mathrm{E}^{*}, \mathrm{R}, \mathrm{A}$ and $\theta$ are the heat of activation, the universal gas constant, pre-exponential factor and rate of heating respectively, $\mathrm{W}_{\mathrm{f}}$ is the mass loss at the completion of the decomposition reaction, $\mathrm{W}$ is the mass loss up to temperature T. Since 1-2RT/ $\mathbf{E}^{*} \sim 1$, the plot of the left hand side of equation (1) against 1/T would give a straight line. The other kinetic parameters; the entropy of activation $\left(\Delta \mathbf{S}^{*}\right)$, enthalpy of activation $\left(\Delta \mathbf{H}^{*}\right)$ and the free energy change of activation $\left(\Delta \mathbf{G}^{*}\right)$ were calculated using the following equations: 


$$
\triangle S^{*}=2.303\left(\log \frac{\mathrm{Ah}}{\mathrm{KT}}\right) \mathrm{R}
$$$$
\triangle \mathbf{H}^{*}=\mathbf{E}^{*}-\mathbf{R T}
$$$$
\triangle G^{*}=H^{*}-\mathbf{T} \triangle S^{*}
$$

Where, (k) and (h) are the Boltzman and planck constants, respectively. The kinetic parameters are listed in Table (4). From the obtained results, it is apparent that $\Delta \mathbf{G}^{*}$ values of the complexes acquire highly positive magnitudes. The high value of the energy of activation of the complexes revealed the high stability of the investigated complexes due to their covalent character [Taakeyama \& Quinn, 1994]. The negative values of $\Delta \mathbf{S}^{*}$ for the degradation process indicates that more ordered activated complex than the reactants and the decomposition reaction is slow [Frost \& Pearson, 1961]. The positive values of $\Delta \mathbf{H}^{*}$ mean that the decomposition process are endothermic.

Table (4): The kinetic and thermodynamic data of the thermal decompositions of cobalt complex.

\begin{tabular}{|c|c|c|c|c|c|c|c|}
\hline Complex & Stage & $\begin{array}{c}\text { Mid } \\
\mathbf{T e m p e r a t u r} \\
\mathbf{e}\left({ }^{\circ} \mathbf{K}\right)\end{array}$ & $\begin{array}{c}\Delta \mathbf{E}^{*} \\
\left(\mathbf{K J ~ m o l}^{-1}\right)\end{array}$ & $\begin{array}{c}\Delta \mathbf{A} \\
\left(\mathbf{S}^{-1}\right)\end{array}$ & $\begin{array}{c}\Delta \mathbf{S}^{*} \\
(\mathbf{K J} / \mathbf{m o l} \mathbf{K})\end{array}$ & $\begin{array}{c}\Delta \mathbf{H}^{*} \\
(\mathbf{K J} / \mathbf{m o l})\end{array}$ & $\begin{array}{c}\Delta \mathbf{G}^{*} \\
(\mathbf{K J} \mathbf{~ m o l})\end{array}$ \\
\hline \multirow{3}{*}[\mathbf{Co}(\mathbf{HL})\mathbf{Cl}_{2}(\mathbf{H}_{2}\boldsymbol{O})]{$.5 \mathbf{H}_{2} \boldsymbol{O}$} & $1^{1 \mathrm{st}}$ & $302-375$ & 213.55 & $4.38 \times 10^{-1}$ & -180.59 & 208.8 & 311.5 \\
\cline { 2 - 8 } & $2^{\text {nd }}$ & $376-582$ & 237.29 & $2.84 \times 10^{-2}$ & -234.04 & 218.3 & 751.7 \\
\cline { 2 - 8 } & $3^{\text {rd }}$ & $584-1273$ & 384.11 & $1.20 \times 10^{-2}$ & -268.58 & 372.5 & 962.1 \\
\hline
\end{tabular}

\subsubsection{Fluorescence spectral studies}

The emission spectra of the Schiff base ligand HL(ATS)and its cobalt (II) complex were investigated at room temperature in DMSO solution Figure (6). The schiff base ligand was characterized by emission 
band around $504 \mathrm{~nm}$ upon photo excitation at $432 \mathrm{~nm}$. The emission observed in the Schiff base ligand was assigned to the $\pi-\pi^{*}$ intraligand fluorescence. The fluorescence of the ligand was probably quenched by the occurrence of a photoinductived electron transfer (PET) process due to the presence of a lone pairs of electrons of the donor atoms in the ligand ( $\mathrm{N}, \mathrm{O}$ and $\mathrm{S}$ atoms). On the other hand, the cobalt(II) complex was characterized by the emission band at $560 \mathrm{~nm}$ with a lower emission than the Schiff base ligand [Majumder, A et al., 2006].

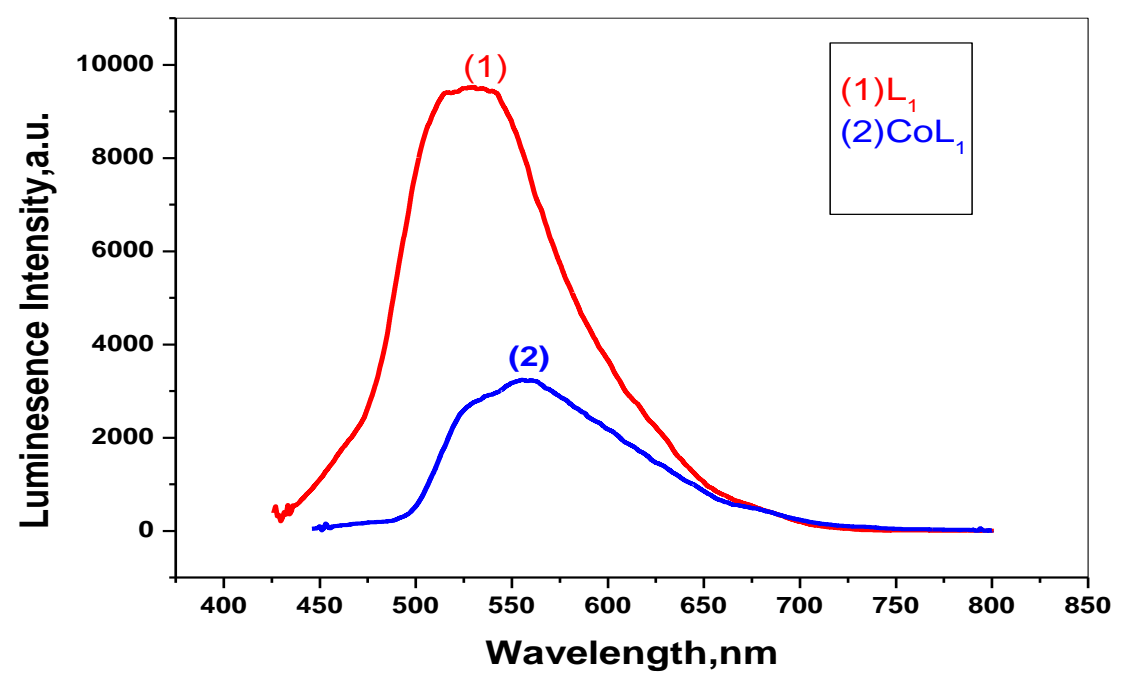

Figure (6): Emission spectra of : (1): Ligand (HL); (2) $\left[\mathrm{Co}(\mathrm{HL}) \mathrm{Cl}_{2}\left(\mathrm{H}_{2} \mathrm{O}\right)\right] .5 \mathrm{H}_{2} \mathrm{O}$.

\subsubsection{Effect of solvent and $\mathrm{pH}$}

The influence of the solvent on Schiff base ligand HL(ATS) and its cobalt (II) complex was studied. The results showed that the optimal solvent for Schiff base ligand and its cobalt (II) complex obtained is DMF as shown in Figure (7-8). The influence of $\mathrm{pH}$ on Schiff base ligand HL(ATS) and its cobalt complex were investigated in both acidic and alkaline media by the addition of dilute $\mathrm{HCl}$ and $\mathrm{NH}_{4} \mathrm{OH}$. The optimum 
signal of Schiff base ligand and its cobalt(II) complex [Liu, Q.X., 2009] were recorded in strongly alkaline conditions. The highest intensity of the Schiff base ligand and its cobalt (II) complex were obtained at $\mathrm{pH}=9.4$ Figure (9.10).

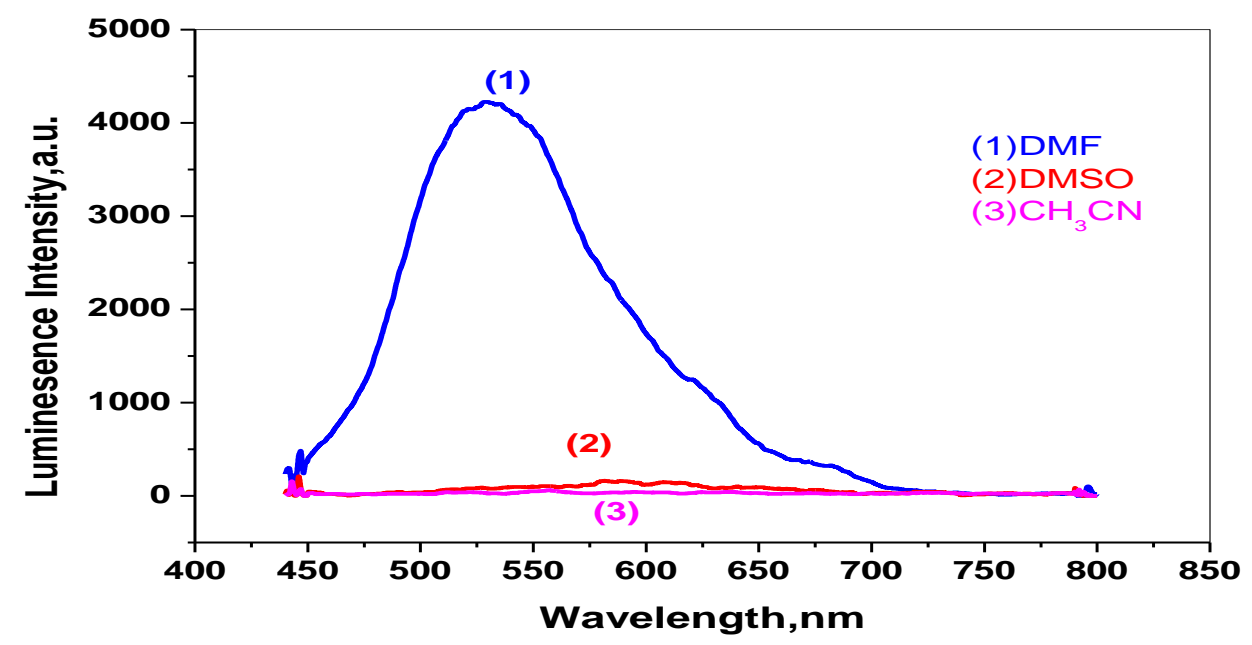

Figure (7): Effect of solvent on Schiff base ligand HL(ATS).

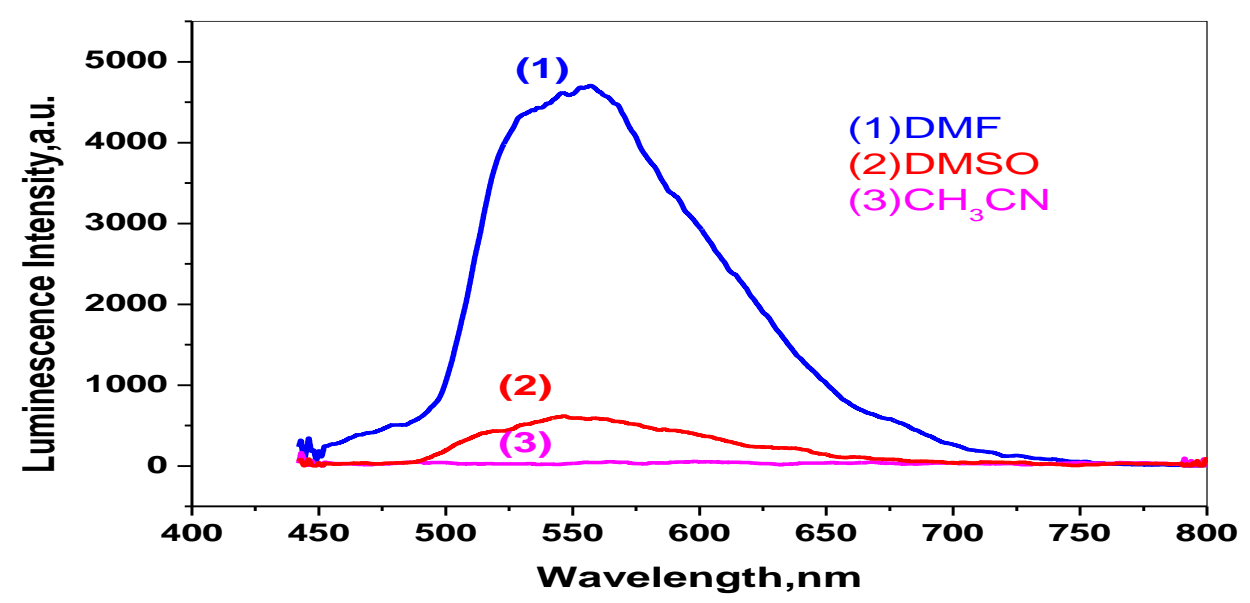

Figure (8): Effect of solvent on $\left[\mathrm{Co}(\mathrm{HL})(\mathrm{Cl})_{2}\left(\mathrm{H}_{2} \mathrm{O}\right)\right] .5 \mathrm{H}_{2} \mathrm{O}$. 


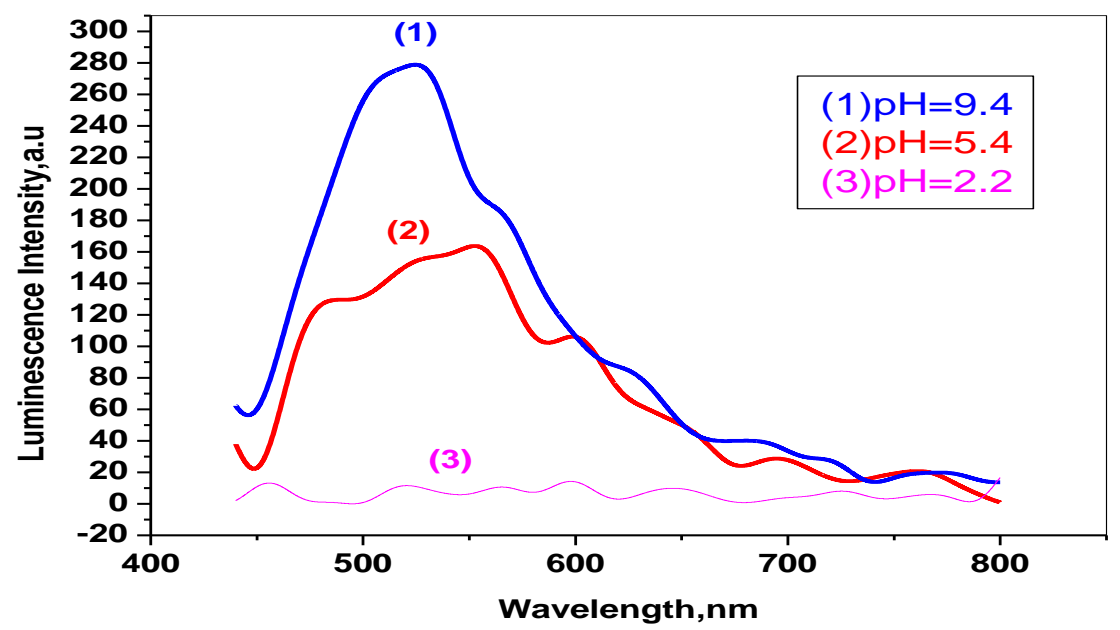

Figure (9): Effect of pH on Schiff base ligand HL(ATS).

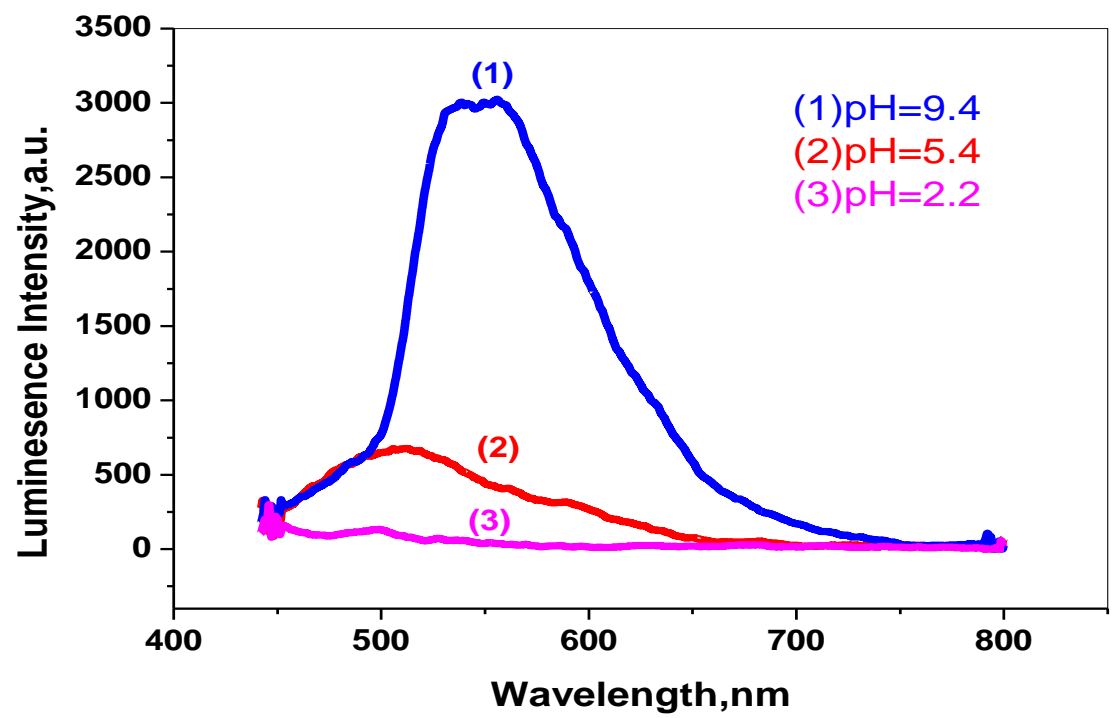

Figure (10): Effect of pH on $\left[\mathrm{Co}(\mathrm{HL})(\mathrm{Cl})_{2}\left(\mathrm{H}_{2} \mathrm{O}\right)\right] .5 \mathrm{H}_{2} \mathrm{O}$.

\section{Conclusion}

In this work, the tridentate Schiff base ligand N-[2acetylthiophene]salicylideneimine HL(ATS) and its cobalt(II) complex were synthesized and characterized using spectroscopic methods. IR 
specta of the Schiff base ligand HL(ATS) showed that tridentate ligand was coordinating through ONS donors atoms of phenolic oxygen, azomethine nitrogen and acetyl thiophene sulfur in cobalt (II) complex.. From magnetic and UV-Vis spectra, it is found that the geometrical structure of cobalt (II) complex is an octahedral. Thermogravimetric analysis revealed that the cobalt (II) complex was studied and the activation thermodynamic parameters such as, activation energy, enthalpy, entropy and Gibbs free energy change of decomposition of cobalt(II) complex decomposition indicated that the their stability was determined by Coate-Redfern method. Fluorescence studies indicated that the Schiff base ligand HL(ATS) and its cobalt (II) complex can serve as potential photoactive materials, as indicated from their characteristic fluorescence properties.

\section{References}

Atkins, R.; Brfwer,G.; Kokto,E.; Mockler, G.M. and Sinn, E., Inorg. Chem., (24) 127-134 (1985).

Bosnich, B. Am. Chem. Soc (90) 627-632 (1968)

Coats, A.W and Redfern, J.P., Nature (20) 68-69 (1964).

Cozzi, P.G., Chem. Soc. Rev., (33) 410-421 (2004).

Dhahagani, K.; Mathan Kumar, S.; Chakkaravarthi, G.; Anitha, K.; Rajesh, J.; Ramu, A and Rajagopal, G., Spectrochim., Acta A (117) 127-137 (2014).

Estrela dos, J.; Santos, E.R.; Dockal, E.T.G and Cavalheiro, J., Therm. Anal. Cal., (79) 243-248 (2003).

Frost, A.A and Pearson, R.G., Kinetica and Mechanisms, Wiley, New York, (1961).

Holm, R.H.; Solomon, E.L.; Majumdar, A and Tenderholt, A.; Coord., Chem. Rev. (255) 993-1015 (2011). 
Lever, A.B.P "Inorganic electronic spectroscopy" $2^{\text {nd }}$ edn, elservier, New York, (1984).

Liu.Q-X, Polyhedron (28) 917-922 (2009).

Majumder, A; Rosair, G.M; Mallick, A; Chattopadhyay, N and Mitra, S, Polyhedron., (25) 1753 (2006).

Nakamoto.K, "Infrared and Raman Spectra of Inorganic and Coordination Compounds", Wiley, New York, (1978).

Neelakantana, M.A; Rusalrajaf; Dharamarajaa, J; Johnsonrajaa, S; Jeyakumarb, T and Pillaic, M.S, Spectrochim. Acta, (2008).

Pouralimardan, O; Chamayou, AC; Janiak, c; HosseiniMonfared, H. Inorg - Chim, Acta, (360) 1599 (2007).

Raman, N.; S.J. Raja, A and Sakthivel, J. Coord. Chem. (62) 691709 (2009).

Saxena, J.K.; Koacher, J.P and Tandon. J.; Antibact. Antifung. Agents, (9) 435-438 (1981).

Small, B.L and Brooker, M.; Polymer, Am. Chem. Soc. Div. Polym. Chem., (39) 213-218 (1998).

Taakeyama, T and Quinn, Fx., Thermal Analysis, Fundamentals and Applications to Polymer Science, John Wiley and Sons, Chichester, (1994).

Usha, A.K and Chandra, S, Synth. React. Inorg. Met-org. Chem., (22) 971 (1992). 


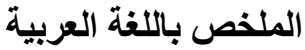

تحضير و دراسه الخواص الطبيعيه ،الكيميائيه ،الحراريه و الضوئيه لمتراكب الكوبلت الثنائى مع قاعده شيف ثلاثيه المخلب المشتقه من 2-امينو فينول مع 2-اسيتيل ثيوفين

\section{مناره احمد ايوب ، ايمان حامد عبد الناصر ، منى عبد العزيز، مريم جرجس رزق سعيد قسم الكيمياء ـبنات_عين شمس.}

1-در اسه الخواص الطبيعيه و الكيميائيه بهدف التعرف على تركيب الليجند العضوي المستخدم و ذللك بتعين درجه الأنصهار و التحليل العنصرى و طيف إمنصاص الاشعه تحت الحمر اءو طيف الكتله و ميكانيكيه التكسير و طيف الرنين النووى المغناطيسي و طيف امتصاص الاشعه فوق بنفسيه و المرئيه و الخاصيه الضوئيه. و قد تم اثبات وجود مجمو عه الازوميثين و الهيدروكسيل الكحوليه و الكبريت لحلقه ثيوفين و تعتبر هذه المركبات ثلاثيه المخلب. 2-نم در اسه تفاعل الليجند المحضر مع ايون الكوبلت الثنائي و تم الحصول على المتر اكب الكوبلت الثنائى فى الحاله الصلبه و تمت در استه و اثبات التركيب الجزيئي و الفر اغى له بو اسطه التحليل العنصرى، مطياف الكتله، ميكانيكيه التكسير، طيف امتصاص الاشعه تحت الحمراء، فوق بنفسيه و المرئيه، الرنين الالكترونى المغزلى و ايضا الخو اص المغناطيسيهو ولئه الحراريه فقد تم التوصل الى ان الثكل الفر اغى ثمانى الاوجه حول ذره الكوبلت الثنائيه و قد اظهرت النتائج انه امكن ترابط الليجند مع الفلز عن طريق زوج الكترونات الحره الموجوده على ذره النيتروجين فى مجمو عه الازوميثين و زوج الالكترونات الحره الموجوده على ذره

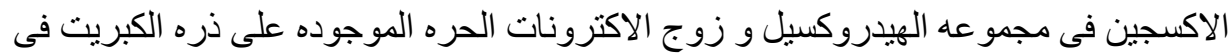

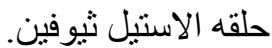

3E* تم در اسه الخواص الحر اريه للمتر اكب و تعيين كل من

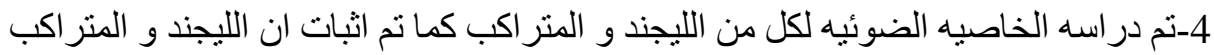
لديهم امكانيه التالق كما تم دراسه تاثير الأس الهيدروجينى و المذيبات المختلفه لكل من الليجند و المتر اكب و اثتتت النتائج ان مذيب ثنائى ميثيل الفورماميد افضل مذيب و افضل أس هيدروجينى

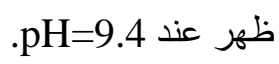

5- النتائج العمليه التى تم الحصول عليها تتفق تماما مع التفسير ات المرجعية. 